\title{
Interface Peptide Mimetics-Rationale and Application as Therapeutic Agents
}

\section{Mythily Srinivasan*}

School of Dentistry and Provaidya LLC, Indiana University- Purdue University at Indianapolis, Indianapolis, IN 46202, USA

\begin{abstract}
Biomolecular recognition via protein-protein interactions (PPI) is central to the signaling events in most physiological and pathological processes. Hence PPI are considered excellent targets for drug development. In recent years there is considerable interest in the design and development of peptide based drugs as antagonists or agonists of PPI. High potency, great selectivity and better safety profile are significant advantages of peptide therapeutics. The following is a brief review of the rationale and modifications in the design of peptide mimetics of PPI interface.
\end{abstract}

Keywords: Protein-protein interactions; Peptide drugs

\section{Introduction}

\section{Protein-protien interaction (PPI) interface as druggable targets}

PPI constitute fundamental mechanisms that support a wide variety of biological functions including cellular growth, maintenance, apoptosis, signaling pathways and metabolic activities. An associated corollary is that altered PPI implicate pathology. Hence blockade or stabilization of PPI could represent an attractive therapeutic strategy for many human diseases. The network of PPI called interactome is highly complex and expansive. PPI occurs when two or more proteins come in proximity guided by biophysical principles that govern molecular recognition. In humans, the PPI interactome is estimated to range from 14,000 binary interactions to over 650,000 multi- component interactions [1,2]. PPI binding sites called interfaces typically range in size between 1200 to $2000 \mathrm{~A}^{2}$. They are made up of few smaller binding pockets scattered across the entire contact area [2]. Molecular recognition is commonly mediated by a subset of interface amino acids, referred to as hot spot residues located on defined secondary structures [3]. Evolutionary constraints on sequence divergence at PPI interfaces ensure that the hot spot residues are highly conserved. Since biophysical principles limit the number of ways of secondary structure packing, the types of interface structural folds are potentially limited $[4,5]$. Hence shared functional characteristics between structurally dissimilar proteins may be attributed to the evolutionary convergence in the interface space $[2,6,7]$. PPI interfaces are identified based on interatomic distance between residue pairs, the interaction between interface residues through water molecules and the buried surface area. In most PPI the hot spot residues at the interface contribute significantly to the free energy of binding, are surrounded by a ring of energetically less critical residues that occlude bulk solvent and mutation of these residues abolish PPI [6].

Collectively the convergent evolution and the minimal binding consensus suggest that the PPI interfaces are excellent targets for drug design and discovery [8-10].

\section{Interface peptide drugs}

Over the past decade considerable efforts have been directed at developing small molecule inhibitors of PPI. The efficacy of small molecule inhibitors are largely limited to a subset of PPI that present tight hydrophobic binding pockets within a relatively smaller area ranging between $300-1000 \mathrm{~A}^{2}[2,9,11]$. However, most PPI interface present non-contiguous distribution of hot spot residues and large surface area with little or no binding pockets. Such features not particularly favorable for development of high affinity small molecule inhibitors [7]. Although biologics with well-defined three dimensional structures such as the recombinant protein or monoclonal antibodies are capable of binding wide target space with high affinity and noteworthy selectivity, their large size often precludes efficient cellular permeability. This compromises the therapeutic efficacy of the biologics especially for intracellular targets $[2,12]$. Efficacious competitive PPI antagonists should be large enough to simultaneously interact with multiple hot spot patches to gain considerable part of the distributed free energy and achieve significant affinity. It is suggested that medium sized molecules with large contact surfaces could achieve nanomolar potency at PPI interfaces and function as better inhibitors [1,9].

Peptides are a hybrid class of drugs that bridge the gap between small molecules and proteins. As opposed to small molecules, peptides can bind large targets with high potency and great selectivity. Consequently peptides exhibit minimal off-target effects. Furthermore, rapid clearance of peptides precludes the accumulation of deleterious metabolites and minimizes the risk of toxicity $[12,13]$. In addition being considerably smaller in size than biologics, peptides are capable of better tissue penetration $[2,14]$. Importantly peptides are amenable to multitudes of modifications such as incorporation of non-natural building blocks and introduction of variety of functional folds which in turn exponentially increases the potential to create panels of peptide analogs with wide range of chemical diversity and functionalities $[2,8,13]$. Although, low proteolytic stability is a critical disadvantage, advances in peptide design and synthesis has led to the development of a rich pipeline of stable, efficacious and cost effective novel peptides with high therapeutic efficacy [10]. The potential for peptide therapeutics in the treatment of diverse medical conditions is exemplified by the rapidly growing market currently estimated at 18 billion dollars [15]. However, a commonly perceived problem associated with peptide drugs is rapid in-vivo clearance, poor bioavailability and the need for specialized delivery mechanim (10.15)

A significant percentage of PPI are mediated by protein peptide interactions [14]. Epitope mimetic design starts from mutagenesis

*Corresponding author: Mythily Srinivasan, MS, PhD, Associate Professor, Oral Pathology, Radiology and Medicine, School of Dentistry, Indiana University, IN 46202, USA, Tel: 3172789686, Fax: 3172783018; E-mail: mysriniv@iupui.edu

Received March 11, 2016; Accepted March 29, 2016; Published March 31, 2016

Citation: Srinivasan M (2016) Interface Peptide Mimetics-Rationale and Application as Therapeutic Agents. Med chem (Los Angeles) 6: 189-194. doi:10.4172/21610444.1000344

Copyright: ( 2016 Srinivasan M. This is an open-access article distributed under the terms of the Creative Commons Attribution License, which permits unrestricted use, distribution, and reproduction in any medium, provided the original author and source are credited. 
Citation: Srinivasan M (2016) Interface Peptide Mimetics-Rationale and Application as Therapeutic Agents. Med chem (Los Angeles) 6: 189-194. doi:10.4172/2161-0444.1000344

and three dimensional structural data, which map the energetically important residues at the interface of interacting proteins. Advances in computational biology have propelled the development of methods to identify hot spot interface residues even if the structure of the PPI complex is not known [16]. The challenge is to recapitulate the structural and conformational properties of the target epitope, in a relatively small scaffold. The primary goal is to transform a prototype PPI peptide into a pharmacologically useful and metabolically stable drug capable of reaching the target organ $[12,13]$. Promising engineering strategies incorporated in peptide structure to confer selectivity and stability can be broadly classified as 1) end-group modifications, 2) peptide bond modifications and 3) peptide mimetics (Tables 1 and 2). Here we briefly

\begin{tabular}{|c|c|c|c|}
\hline End group modifications & $\begin{array}{c}\text { Acetylation, amidation, PEGylation, } \\
\text { glycosylation. }\end{array}$ & $\begin{array}{l}\text { Stabilize active conformation, } \\
\text { secondary structure. }\end{array}$ & Minimum change to peptide structure. \\
\hline Cyclization & & Stabilize structure & $\begin{array}{l}\text { Peptide structure modified without affecting } \\
\text { the critical functional groups }\end{array}$ \\
\hline Peptide-bond modifications & $\begin{array}{l}\text { Use of D-amino acids, backbone extensions by } \\
\beta \text { amino acids, methylation of amide nitrogen, } \\
\text { hydrogen bond surrogate, stapling, hairpins, side- } \\
\text { chain modifications with similar natural or non- } \\
\text { natural amino acids. }\end{array}$ & $\begin{array}{c}\text { Greater resistance against protease } \\
\text { degradation, increased metabolic stability }\end{array}$ & $\begin{array}{c}\text { Considerable alterations in the biochemical } \\
\text { properties, hydrophobicity conformation, and } \\
\text { flexibility of candidate peptide drug }\end{array}$ \\
\hline Peptide mimetics & $\begin{array}{l}\text { Peptide bond isosteres, organic non- peptide } \\
\text { molecules, functional groups positioned on non- } \\
\text { peptide scaffold }\end{array}$ & $\begin{array}{l}\text { Increased stability, high affinity and } \\
\text { selectivity }\end{array}$ & $\begin{array}{l}\text { Minimal similarity with the candidate peptide } \\
\text { drug }\end{array}$ \\
\hline
\end{tabular}

Table 1: Peptide modifications and effects. discuss the modifications with examples restricted to the interface peptides of PPI other than the antigen:antibody and the peptide: major histocompatibility (human leukocyte antigen-HLA) complexes.

\section{End group modifications}

Linear peptides of residues that comprise the hot-spot patch commonly constitute the first generation inhibitors of specific PPI $[10,17,18]$. Since free peptides are rapidly degraded by exopeptidases, the end-protection strategy has been widely used to improve enzymatic stability. The rationale is based on the observations that the biological stability and activity of many endogenous peptides such as the neuropeptides and melanocyte-releasing hormone are attributed to

\begin{tabular}{|c|c|c|c|c|c|}
\hline $\begin{array}{l}\text { Peptide } \\
\text { modification }\end{array}$ & & PPI & Indication & Status & Ref \\
\hline \multirow[t]{10}{*}{$\begin{array}{l}\text { End-group } \\
\text { modifications }\end{array}$} & $\begin{array}{l}\text { Acetylation } \\
\text { Amidation }\end{array}$ & CD80-CD28 & Autoimmune & Preclinical & {$[29,30]$} \\
\hline & $\begin{array}{l}\text { Acetylated } \\
\text { peptide }\end{array}$ & GnRH:gonadotropin & $\begin{array}{l}\text { Prostate cancer, } \\
\text { endometriosis, multiple indications }\end{array}$ & $\begin{array}{l}\text { Clinical } \\
\text { Preclinical }\end{array}$ & {$[20]$} \\
\hline & Acetylated & GHRH:GH & $\begin{array}{l}\text { Pituitary dwarfism } \\
\text { Retroviral lipodystrophy }\end{array}$ & $\begin{array}{l}\text { Diagnostic } \\
\text { Clinical }\end{array}$ & [23-25] \\
\hline & Amidated & $\begin{array}{l}\text { Amylin:receptor } \\
\text { Amylinomimetic }\end{array}$ & $\begin{array}{l}\text { Adjunct } \\
\text { Diabetes }\end{array}$ & Clinical & {$[26]$} \\
\hline & Amidated & $\begin{array}{l}\text { Thymosin a1: } \\
\text { receptor }\end{array}$ & $\begin{array}{l}\text { Hepatitis B and C } \\
\text { Cancer }\end{array}$ & Clinical & {$[31]$} \\
\hline & $\begin{array}{l}\text { Acetylation } \\
\text { amidation }\end{array}$ & ATR: $\beta$-arrestin biased ligand & Heart failure & Clinical & [32-34] \\
\hline & acylated & $\mathrm{AXH}: \mathrm{CIC}$ & Spinocerebellar ataxis & Preclinical & {$[35]$} \\
\hline & PEGylation & Exedin-4 & & & \\
\hline & \multirow[t]{2}{*}{ Cyclization } & $\begin{array}{l}\text { Integrin inhibitors } \\
\text { RGD peptides }\end{array}$ & $\begin{array}{l}\text { Vitreoretinal diseases } \\
\text { Cancer }\end{array}$ & $\begin{array}{l}\text { Clinical } \\
\text { Preclinical }\end{array}$ & [40-42] \\
\hline & & GLP-1: receptor & Diabetes & Clinical & {$[44,45]$} \\
\hline \multirow{9}{*}{$\begin{array}{l}\text { Peptide } \\
\text { backbone } \\
\text { modification }\end{array}$} & \multirow[t]{6}{*}{$\begin{array}{l}\text { Stapled } \\
\text { peptides }\end{array}$} & ICN1:CSL:MAML1 & Leukemia & Preclinical & {$[48]$} \\
\hline & & BID:BCL ${ }_{-x L} / B L_{-w}$ & Cancer & Preclinical & [49] \\
\hline & & p53-MDM2 & Cancer & Preclinical & {$[50,51]$} \\
\hline & & $\beta$-catenin-TCF & Cancer & Preclinical & [52] \\
\hline & & ApoE: ABCA-1 & $\begin{array}{l}\text { Alzheimer's disease, } \\
\text { Coronary syndrome }\end{array}$ & Preclinical & [53] \\
\hline & & VDR-coactivator & & Preclinical & {$[54,55]$} \\
\hline & \multirow{3}{*}{$\begin{array}{l}\text { Retro- } \\
\text { inverso }\end{array}$} & CD4, CD28 & Autoimmune & Preclinical & [30] \\
\hline & & Icatibant & Angioedema & Clinical & [58] \\
\hline & & VEGF: receptor & Cancer & Preclinical & [59] \\
\hline \multirow[t]{3}{*}{$\beta$-hairpins } & \multirow[t]{3}{*}{$\beta$-peptides } & IFN-ү:receptor & Preclinical & & [63] \\
\hline & & Transthyretin: $A \beta$ & Alzheimer's disease & Preclinical & [64] \\
\hline & & p53-Human MDM2 & Cancer & Clinical & {$[51,65]$} \\
\hline
\end{tabular}

$\mathrm{GnRH}$ : gonadotropin releasing hormone; GHRH: growth hormone releasing hormone; ATR: angiotensin II receptor; $\mathrm{AXH}$ : $\mathrm{AXH}$ domain of ataxin-1; CIC: capicua transcriptional repressor; GLP: glucagon like peptide; ICN: cytoplasmic tail of NOTCH1; CSL: DNA-bound transcription factor; MNML: mastermind like; BCL-XL: BCL-2 anti-apoptotic protein; BID: BCL-2 pro-apoptotic protein; MDM2: mouse double minute 2 protein; TCF: T-cell factor; ApoE: apolipoprotein e; ABCA-1: ATP-binding cassette transporter A1; VDR: vitamin $D$ receptor; VEGF: vascular endothelial growth factor; $A \beta$ : amyloid-beta.

Table 2: Interface peptide drugs. Interface peptide drugs in different stages of development: A non-exhaustive list of peptide drugs that include hot spot residues at the protein-protein interaction (PPI) interface that are being evaluated in preclinical models, clinical trials or clinical use. 
amino-acetylation and carboxy amidation $[8,19]$. Blocking of the endgroups by acetyl and amide groups has been shown to extend the invivo half-life of synthetic peptides by several folds. Additionally, amino terminal acetylation presumably increases the peptide lipophilicity enhancing the membrane permeability and passage across the intestinal or blood brain barrier $[8,16,19]$. An acetate salt of a peptide analog of the gonadotropin releasing hormone $(\mathrm{GnRH})$ acts as a potent inhibitor of gonadotropin secretion and has diverse clinical applications [20].

Acetate salt of a synthetic peptide amide derived from the aminoterminal sequence of the human growth hormone-releasing hormone (GHRH or GRF) (sermorelin) has been shown to block GH:GHRH interaction [21,22]. Sermorelin is used for the diagnosis of pituitary dwarfism and also has potential applications in the management of retroviral induced lipodystrophy [23-25]. Amylin, also known as islet amyloid polypeptide is a hormone co-secreted with insulin by the $\beta$ - cells of the pancreas. Amylin regulates plasma glucose by slowing gastric emptying and decreasing postprandial glucagon secretion. An amidated peptide analog of human amylin, pramlintide is used as an amylin receptor agonist in the management of diabetes. Exenatide, an amidated peptide mimetic of the glucagon like peptide-1 (GLP$1)$, has been shown to bind GLP-1 receptors and enhance glucose dependent insulin secretion in diabetes [26,27]. Modifications such as attachment of long fatty acids to the peptides or co-synthesis with Fc fragments have been introduced to increase plasma half-life of GLP-1 analogs [28]. We have shown that end groups blocked peptides derived from the T-cell costimulatory receptor, CD28 inhibit the CD28:B7 receptor:ligand interactions and suppress disease in preclinical models of autoimmune diseases [29,30] (Figure 1A). Treatment with an amidated immunomodulatory peptide thymosin $\alpha-1$ has been shown to block the endogenous peptide and exhibit antitumor activity in many human cancers [31]. Selective $\beta$-arrestin biased peptide ligand based on the sequence of angiotensin type II has been shown to block the angiotensin II receptor, reduced blood pressure and increased cardiac performance [32-34]. Autosomal dominant spinocerebellar ataxias (SCAs) are a complex group of debilitating and neurodegenerative diseases causally related to ataxin-1(ATX1) aggregation. ATX1 interacts with other transcriptional regulators such as $\mathrm{CIC}$. AXH is a functional domain of ATX1 critical for dimerization. A linear derived from the amino terminus of CIC has been shown to compete dimer formation of AXH and hence prevent ATX1 aggregation [35]. Conjugation with carbohydrate moieties at the amino and carboxy termini or pegylation to block charges at the end-groups have also been shown to enhance the stability of synthetic peptides in-vivo $[19,36]$.

\section{Cyclization}

Cyclization of peptides has been suggested as a strategy to overcome the metabolic instability, introduce structural constraints and reduce flexibility. Additionally the rigidity of the cyclic peptide can often increase affinity and reduce entropy loss upon interaction with its molecular target $[37,38]$. Linear peptides can be cyclicized head to tail, head or tail to side-chain or side-chain to side-chain. The most common approach has been to synthesize a heterodetic cyclic peptide forming a disulfide bridge between two cysteine residues [19,38,39]. Cyclic insulin peptide and integrin antagonists are some of the examples of interface peptides that exhibit high affinity and potency as PPI inhibitors $[10,40,41]$. Integrins are heterodimeric receptors that play
$\mathbf{A}$

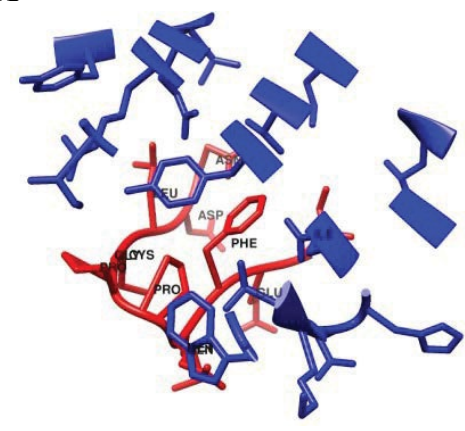

D

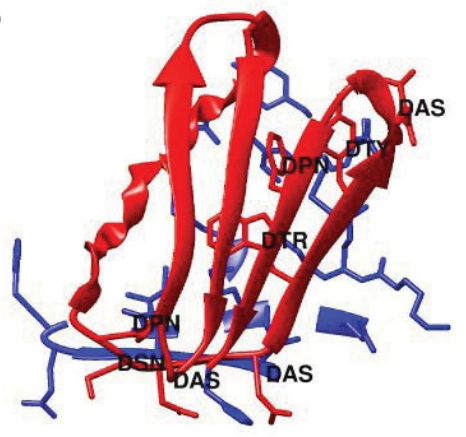

B

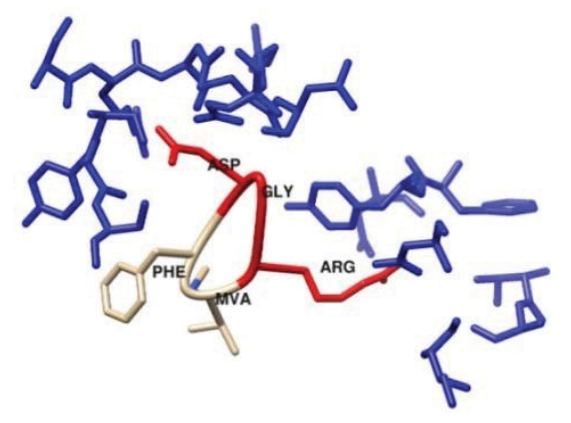

$\mathbf{E}$

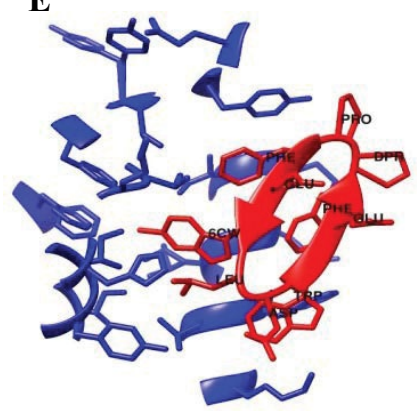

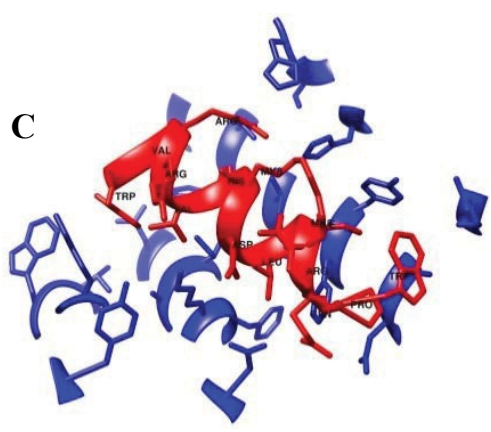

Figure 1: Molecular model or solved crystal structures of peptide drugs in the context of PPI interface. (A) Molecular model of end-groups blocked a CD80 competitive antagonistic peptide in complex with the solution structure of CD80 (PDB 1AH); Crystal structure of (B) cyclic RGD peptide in complex with the avB3 integrin (PDB: 1L5g); (C) phage display derived D- amino acid peptide in complex with vascular endothelial growth factor A (VEGF-A) (PDB:4GLS); (D) human MDM2 in complex with a p53 D-amino acid peptide mimetic (PDB: 3LNJ); (E) beta-catenin in complex with a stapled peptide inhibitor (PDB: 4 DJS). The residues of the peptide at each PPI interface are labeled. 
significant roles in cell-cell or cell-extracellular matrix interactions. The integrin receptors bind the RGD tripeptide motif containing ligands and play critical roles in tumor angiogenesis and metastasis. Cylic RGD peptide $\mathrm{c}(\mathrm{RGDf}(\mathrm{NMe}) \mathrm{V})$ have been shown to exhibit sub-nanomolar antagonistic activity for $\alpha v \beta 3$ receptor and nanomolar affinities for $\alpha 5 \beta 1$ as well as high selectivity towards the platelet receptor $\alpha \mathrm{I} \beta 3$ (Figure 1B). Different types of cyclized RGD peptides have been promising as inhibitors of angiogenesis in glioblastoma and head and neck cancer in clinical trials [40-42]. Covalent synthesis with the RGD peptide increased the permeability of the synthetic thymosin $\alpha-1$ peptide [43]. Cyclic constraints introduced by linkage between side-chains of residues 2 and 5 in an 11-residue peptide derived from the amino terminus of the GLP-1 produced analogs that bound GLP-1 receptor at nanomolar concentrations $[44,45]$. Fusion of the signaling domain of IFN- $\gamma$ with the cyclic peptide that recognizes the binding pocket of platelet derived growth factor $\beta$ receptor (PDGFR- $\beta$ ) helped develop an efficacious drug for hepatic fibrosis and potentially cancer metastasis as PDGFR- $\beta$ is abundantly expressed in activated fibroblasts [46].

\section{Stapled peptides}

Peptide stapling is a recently developed method to efficiently target intracellular PPI by peptide drugs. Stapling constrains the conformation of short peptides, improves stability and enhances cell permeability. It commonly involves covalently linking side chains of the amino acids on the same face of $\alpha$-helix $[2,8,12]$. Stapled peptides are synthesized via incorporation of two $\alpha$-methyl and $\alpha$-alkenyl amino acids at defined positions in the peptide, followed by olefin metathesis to close the helix-spanning hydrocarbon bridge. Both the hydrocarbon bridge and the terminal methyl groups are critical for maximal effectiveness of the structurally constrained peptide agents [47]. This technology has been successfully utilized to target the multi-component NOTCH transcription factor complex. The cytoplasmic tail of NOTCH1 (ICN) engages a DNA-bound transcription factor CSL and presents a shallow groove along the interface for hosting the co-activator mastermind like 1 (MAML1) protein. The resulting ICN1:CSL:MAML1 ternary complex mediate transactivation of target genes. Stapled peptide analogs of the 16 amino-acid stretch of MAML1 acted as high affinity antagonists of NOTCH1 transcription and inhibited cancer progression in a mouse model of leukemia [48]. Similarly an all hydrocarbon stapled peptide designed to mimic the $\mathrm{Bcl}-2$ homology $(\mathrm{BH}) 3$ interacting domain of the pro-apoptotic BID protein has been shown to adopt a stable a-helical conformation, exhibit excellent cell-permeability and inhibit tumor growth [49,50]. p53 is a transcription factor that modulates the expression of numerous target genes. Human analog of mouse double minute 2 protein (HMDM2) has been shown to act as an antagonist of p53 and also modulate the biological outcomes downstream of p53 depending on the nature of the triggering signal. Overexpression of HDM2 in tumors reduces the availability of free p53 for tumor suppression. A linear peptide derived from the transactivation domain of $\mathrm{p} 53$ has been shown to adopt $\alpha$-helical conformation in the hydrophobic binding pocket of HMDM2. However the free peptide was unstructured and rapidly degraded. Recently phage derived stapled peptide analogs designed to stabilize the $\alpha$-helical conformation of the p53 peptide in the context of the MDM2 interface has been shown to disrupt the p53:MDM2 complex and are currently being evaluated for anti-tumor effects in patients with advanced solid tumors or lymphomas expressing wild-type p53 in humans [51,52]. Wnt (Wingless and INT1) signal transduction cascade regulates the expression of numerous genes involved in cell differentiation, proliferation, and survival. The transmission of the Wnt diffusible ligand from the plasma membrane to the nucleus is regulated by $\beta$-catenin and associated components including axin. As opposed to a linear peptide derived from the $\beta$-catenin binding domain of axin (Axin-CBD), an all hydrocarbon stapled peptide analog of the Axin-cBD has been shown to inhibit the interaction between $\beta$-catenin and the DNA-bound transcriptional regulator T-cell factor and suppress the oncogenic Wnt pathway [53] (Figure 1C). A helical peptide mimetics of the ATP-binding cassette transporter $\mathrm{A} 1$ (ABCA1) interacting apolipoprotein e or apolipoprotein $\mathrm{A} 1$ has been shown to act as the ABCA-1 agonists and prevent reverse cholesterol transfer and atherosclerosis [54]. A stapled peptide derived from the LXXXL motif of a vitamin D receptor coactivator has been shown to block the VDR:coactivator interaction and inhibit VDR mediated transcription with potential application in the treatment of Paget's disease and osteoporosis $[55,56]$.

\section{Retro-inverso peptides}

As opposed to the rapid degradation of L-amino acid polypeptides, the proteolytic machinery is not well equipped to deal with the enantiomers or D-amino acid polypeptides [57]. Systematic inversion of the stereochemistry at the peptide backbone alpha- carbons with the use of D-amino acids when coupled with chain reversal can yield proteolytically stable retro-inverso peptide isomers. However, loss of crucial backbone hydrogen-bonding through peptide bond reversal can compromise the biological potential. Hence, partial rather than global retro-inverso isomers to stabilize hydrolysis-prone peptide bonds while maintaining the side chain topology that closely resembles the native sequence has been suggested as a better strategy for developing therapeutic peptides [58]. Icatibant is a partial retro-inverso interface peptide drug with a half-life of over $1 \mathrm{hr}$ for the treatment of angioedema [59]. Developed to block the interaction between the prostaglandin and the bradykinin receptor-2 (BR-2), lcatibant is a peptide mimic of the amino terminus of BR-2 with four substituted non- natural amino acids and one $\mathrm{D}$ amino acid. Retro-inverso peptides derived from the ligand binding motif of the T cell co-receptor CD4 or the costimulatory molecule $\mathrm{CD} 28$ have been shown to prevent inflammation and ameliorate pathology in mouse models of multiple sclerosis [30]. Using mirror image phage display $\mathrm{D}$-amino acid peptides have been developed as high affinity antagonists of the vascular endothelial growth factor (VEGF): receptor interactions. Select D-amino acid analog of VEGF-A has been shown to be nonimmunogenic and metabolically stable with longer half-life in-vivo in mice [60] (Figure 1D).

\section{$\beta$-peptides}

Amongst the secondary structures at PPI interface, $\beta$-hairpin scaffold is used by many proteins for biomolecular recognition (Figure 1D). Typically $\beta$ hairpin is composed of two consecutive hydrogen-bonded antiparallel $\beta$-strands connected by a loop sequence predominantly less than five residues in length $[16,61]$. Specific $\beta$-hairpin epitope mimetics have been designed by transplantation of the loop sequence of a protein of known structure onto a hairpin stabilizing template $[62,63]$. This strategy has been used to design $\beta$ hairpin peptide mimics of the protruding loop in the extracellular domain of the IFN- $\gamma$ receptor to inhibit INF- $\gamma$ binding [64]. Transformation of the amyloid- $\beta$ (A $\beta$ ) aggregation facilitating residues from transthyretin onto a $\beta$-hairpin scaffold has been used to develop peptides that inhibit $A \beta$ plaque and fibril formation. These $A \beta$ peptide antagonists are evaluated as potential therapeutic agents for Alzheimer's disease [65]. Integrating structural information and data from mutagenesis $\beta$ - hairpin mimic that incorporate three hot spot residues from the p53 interface on one strand of the hairpin has been shown to exhibit nanomolar affinity to HMDM2 [52,66] (Figure 1E).

\section{Conclusions}

Sequence and structural data of PPI interfaces are increasingly 
Citation: Srinivasan M (2016) Interface Peptide Mimetics-Rationale and Application as Therapeutic Agents. Med chem (Los Angeles) 6: 189-194. doi:10.4172/2161-0444.1000344

adopted as valid targets for drug design and development. Considerable efforts have been directed on developing organic compounds as small molecule PPI inhibitors in the past decade, but have not been largely successful. More recently focus has turned towards developing rationally designed peptide strategies to harness PPI interface as potential therapeutic targets. Included in this review are several modifications introduced in the peptide design to develop new class of investigational agents capable of targeting and blocking several classes of proteins previously considered intractable such as multi-component complexes and PPI with extended interfaces. However, the excitement, enthusiasm and the enormous potential should be tempered with cautious expectations as many of these interface peptide mimetics are in preclinical or early phase clinical trials in humans.

\section{References}

1. London N, Raveh B, Schueler-Furman O (2013) Druggable protein-protein interactions-- from hot spots to hot segments. Curr Opin Chem Biol 17: 952-959.

2. Tsomaia N (2015) Peptide therapeutics: targeting the undruggable space. Eur J Med Chem 94: 459-470.

3. Winter C, Henschel A, Tuukkanen A, Schroeder M (2012) Protein interactions in 3D:from interface evolution to drug discovery. J Struct Biol 179: 347-358.

4. Andreani J, Guerois R (2014) Evolution of protein interactions: from interactomes to interfaces. Arch Biochem Biophys 554: 65-75.

5. Gao M, Skolnick J (2012) The distribution of ligand-binding pockets around protein- protein interfaces suggests a general mechanism for pocket formation. Proc Natl Acad Sci USA 109: 3784-3789.

6. Bogan AA, Thorn KS (1998) Anatomy of hot spots in protein interfaces. J Mol Biol 280: 1-9.

7. Chen J, Ma X, Yuan Y, Pei J, Lai L (2014) Protein-protein interface analysis and hot spots identification for chemical ligand design. Curr Pharm Des 20: 1192-1200.

8. Adessi C, Soto C (2002) Converting a peptide into a drug: strategies to improve stability and bioavailability. Curr Med Chem 9: 963-978.

9. Buchwald P (2010) Small-molecule protein-protein interaction inhibitors: therapeutic potential in light of molecular size, chemical space, and ligand binding efficiency considerations. IUBMB Life 62: 724-731.

10. Fosgerau K, Hoffmann T (2015) Peptide therapeutics: current status and future directions. Drug Discov Today 20: 122-128.

11. Smith MC, Gestwicki JE (2012) Features of protein-protein interactions that translate into potent inhibitors: topology, surface area and affinity. Expert Rev Mol Med 14: e16.

12. Vlieghe P, Lisowski V, Martinez J, Khrestchatisky M (2010) Synthetic therapeutic peptides: science and market. Drug Discov Today 15: 40-56.

13. Uhliga T, Kyprianoua T, Martinellia FG, Oppicia CA, Heiligersa D, et al. (2014) The emergence of peptides in the pharmaceutical business: Fromexploration to exploitation. EuPA Open Proteomics 4: 58-69.

14. Olmez EO, Akbulut BS (2012) Protein-Peptide Interactions Revolutionize Drug Development. In: Binding Protein (Abdelmohsen K), Olmez and Akbulut, Licensee InTech. pp: 49-70.

15. (2014) Global peptide therapeutics market and pipeline insights.

16. Wojcik P, Berlicki L (2016) Peptide-based inhibitors of protein-protein interactions. Bioorg Med Chem Lett 26: 707-713.

17. Bray BL (2003) Large-scale manufacture of peptide therapeutics by chemical synthesis. Nat Rev Drug Discov 2: 587-593.

18. Srinivasan M, Dunker AK (2012) Proline rich motifs as drug targets in immune mediated disorders. Int J Pept 634769.

19. Goodwin D, Simerska P, Toth I (2012) Peptides as therapeutics with enhanced bioactivity. Curr Med Chem 19: 4451-4461.

20. Wilson AC, Meethal SV, Bowen RL, Atwood CS (2007) Leuprolide acetate: a drug of diverse clinical applications. Expert Opin Investig Drugs 16: 1851-1863.

21. Cervini LA, Donaldson CJ, Koerber SC, Vale WW, Rivier JE (1998) Human growth hormone-releasing hormone hGHRH(1-29)-NH2: systematic structureactivity relationship studies. J Med Chem 41: 717-727.
22. Esposito P, Barbero L, Caccia P, Caliceti P, D'Antonio M, et al. (2003) PEGylation of growth hormone-releasing hormone (GRF) analogues. Adv Drug Deliv Rev 55: 1279-1291.

23. Koutkia P, Meininger G, Canavan B, Breu J, Grinspoon S (2004) Metabolic regulation of growth hormone by free fatty acids, somatostatin, and ghrelin in HIV-lipodystrophy. Am J Physiol Endocrinol Metab 286: E296-E303.

24. Smith PJ, Brook CG (1988) Growth hormone releasing hormone or growth hormone treatment in growth hormone insufficiency? Arch Dis Child 63: 629-634.

25. Tauber MT, Pienkowski C, Landier F, Gunnarsson R, Rochiccioli P (1989) Modification of 24-hour growth hormone secretion after continuous subcutaneous infusion of growth hormone-releasing hormone (GHRH (129)NH2) in short children with low 24-hourgrowth hormone secretion. Acta Paediatr Scand Suppl 349: 117-122; discussion 123-114.

26. Schmitz O, Brock B, Rungby J (2004) Amylin agonists: a novel approach in the treatment of diabetes. Diabetes 53: S233-238.

27. Underwood CR, Garibay P, Knudsen LB, Hastrup S, Peters GH, et al. (2010) Crystal structure of glucagon-like peptide- 1 in complex with the extracellular domain of the glucagon-like peptide-1 receptor. J Biol Chem 285: 723-730.

28. Lau J, Bloch P, Schaffer L, Pettersson I, Spetzler J, et al. (2015) Discovery of the Once-Weekly Glucagon-Like Peptide-1 (GLP-1) Analogue Semaglutide. J Med Chem 58: 7370-7380.

29. Srinivasan M, Lu D, Eri R, Brand DD, Haque A, et al. (2005) CD80 binding polyproline helical peptide inhibits T cell activation. J Biol Chem 280: 1014910155.

30. Srinivasan M, Wardrop RM, Gienapp IE, Stuckman SS, Whitacre CC, et al (2001) A retro-inverso peptide mimic of CD28 encompassing the MYPPPY motif adopts a polyproline type II helix and inhibits encephalitogenic T cells in vitro. J Immunol 167: 578-585.

31. Danielli R, Fonsatti E, Calabro L, Di Giacomo AM, Maio M (2012) Thymosin alpha1 in melanoma: from the clinical trial setting to the daily practice and beyond. Ann N Y Acad Sci 1270: 8-12.

32. Holloway AC, Qian H, Pipolo L, Ziogas J, Miura S, et al. (2002) Side-chain substitutions within angiotensin II reveal different requirements for signaling, internalization, and phosphorylation of type $1 \mathrm{~A}$ angiotensin receptors. Mol Pharmacol 61: 768-777.

33. Violin JD, DeWire SM, Yamashita D, Rominger DH, Nguyen L, et al. (2010) Selectively engaging beta-arrestins at the angiotensinll type 1 receptor reduces blood pressure and increases cardiac performance. J Pharmacol ExpTher 335 572-579.

34. Monasky MM, Taglieri DM, Henze M, Warren CM, Utter MS, et al. (2013) The beta-arrestin-biased ligand TRV120023 inhibits angiotensin II- induced cardiac hypertrophy while preserving enhanced myofilament response to calcium. Am J Physiol Heart Circ Physiol 305: H856-H866.

35. de Chiara C, Menon RP, Kelly G, Pastore A (2013) Protein-protein interactions as a strategy towards protein-specific drug design: the example of ataxin-1. PLoS One 8: e76456

36. Jevsevar S, Kunstelj M, Porekar VG (2010) PEGylation of therapeutic proteins Biotechnol J 5: 113-128.

37. Katsara M, Tselios T, Deraos S, Deraos G, Matsoukas MT, et al. (2006) Round and round we go: cyclic peptides in disease. Curr MedChem 13: 2221-2232.

38. Tapeinou A, Matsoukas MT, Simal C, Tselios T (2015) Review cyclic peptides on a merry-go-round; towards drug design. Biopolymers 104: 453-461.

39. Jagadish K, Camarero JA (2010) Cyclotides, a promising molecular scaffold for peptide-based therapeutics. Biopolymers 94: 611-616.

40. Liu Z, Wang F, Chen X (2008) Integrin alpha(v)beta(3)-Targeted Cancer Therapy. DrugDev Res 69: 329-339.

41. Tucker GC (2006) Integrins: molecular targets in cancer therapy. Curr Oncol Rep 8: 96-103

42. Xiong JP, Stehle T, Zhang R, Joachimiak A, Frech M, et al. (2002) Crystal structure of the extracellular segment of integrin alpha Vbeta3 in complex with an Arg-Gly-Asp ligand. Science 296: 151-155.

43. Lao X, Liu M, Chen J, Zheng H (2013) A tumor-penetrating peptide modification enhances the antitumor activity of thymosin alpha 1. PLoS One 8: e72242.

44. Hoang HN, Song K, Hill TA, Derksen DR, Edmonds DJ, et al. (2015) Short 
Citation: Srinivasan M (2016) Interface Peptide Mimetics-Rationale and Application as Therapeutic Agents. Med chem (Los Angeles) 6: $189-194$. doi:10.4172/2161-0444.1000344

Hydrophobic Peptides with Cyclic Constraints Are Potent Glucagon-like Peptide-1 Receptor (GLP-1R) Agonists. J Med Chem 58: 4080-4085.

45. Jespersen MJ, Knop FK, Christensen M (2013) GLP-1 agonists for type 2 diabetes: pharmacokinetic and toxicological considerations. Expert Opin Drug Metab Toxicol 9: 17-29.

46. Bansal R, Prakash J, De Ruiter M, Poelstra K (2014) Targeted recombinant fusion proteins of IFNgamma and mimetic IFNgamma with PDGFbetaR bicyclic peptide inhibits liverfibrogenesis in vivo. PLoS One 9: e89878.

47. Walensky LD, Bird GH (2014) Hydrocarbon-stapled peptides: principles, practice, and progress. J Med Chem 57: 6275-6288.

48. Moellering RE, Cornejo M, Davis TN, Del Bianco C, Aster JC, et al. (2009) Direct inhibition of the NOTCH transcription factor complex. Nature 462: 182 188.

49. Denisov AY, Chen G, Sprules T, Moldoveanu T, Beauparlant $P$, et al. (2006) Structural model of the BCL-W-BID peptide complex and its interactions with phospholipid micelles. Biochemistry 45: 2250-2256.

50. Robin AY, Kumar KK, Westphal D, Wardak AZ, Thompson GV, et al. (2015) Crystal structure of Bax bound to the $\mathrm{BH} 3$ peptide of Bim identifies important contacts for interaction. Cell Death Dis 6: e1809.

51. Liu L, Bernard D, Wang S (2015) Case Study: discovery of inhibitors of the MDM2-p53 protein-protein interaction. Methods Mol Biol 1278: 567-585.

52. Zhao Y, Aguilar A, Bernard D, Wang S (2015) Small-molecule inhibitors of the MDM2-p53 protein-protein interaction (MDM2 Inhibitors) in clinical trials for cancer treatment. J Med Chem 58: 1038-1052.

53. Grossmann TN, Yeh JT, Bowman BR, Chu Q, Moellering RE, et al. (2012) Inhibition of oncogenic Wnt signaling through direct targeting of beta-catenin Proc NatIAcad Sci USA 109: 17942-17947.

54. Hafiane A, Bielicki JK, Johansson JO, Genest J (2015) Novel Apo E-Derived ABCA1 Agonist Peptide (CS-6253) Promotes Reverse Cholesterol Transport and Induces Formation of prebeta-1 HDL In Vitro. PLoS One 10: e0131997.

55. Demizu Y, Nagoya S, Shirakawa M, Kawamura M, Yamagata N, et al. (2013) Development of stapled short helical peptides capable of inhibiting vitaminD receptor (VDR)-coactivator interactions. Bioorg Med Chem Lett 23: 4292-4296.
56. Mita Y, Dodo K, Noguchi-Yachide T, Miyachi H, Makishima M, et al. (2010) LXXLL peptide mimetics as inhibitors of the interaction of vitamin $D$ receptor with coactivators. Bioorg Med Chem Lett 20: 1712-1717.

57. Funke SA, Willbold D (2009) Mirror image phage display--a method to generate D- peptide ligands for use in diagnostic or therapeutical applications. Mol Biosyst 5: 783-786.

58. Zhou N, Luo Z, Luo J, Fan X, Cayabyab M, et al. (2002) Exploring thestereochemistry of CXCR4-peptide recognition and inhibiting HIV-1 entry with D-peptides derived from chemokines. J Biol Chem 277: 17476-17485.

59. Bock T, Chen WH, Ori A, Malik N, Silva-Martin N, et al. (2014) An integrated approach for genome annotation of the eukaryotic thermophile Chaetomium thermophilum. Nucleic Acids Res 42: 13525-13533.

60. Mandal K, Uppalapati M, Ault-Riche D, Kenney J, Lowitz J, et al. (2012) Chemical synthesis and X-ray structure of a heterochiral \{D-protein antagonist plusvascular endothelial growth factor $\}$ protein complex by racemic crystallography. Proc Natl Acad Sci USA 109: 14779-14784.

61. Jubb H, Higueruelo AP, Winter A, Blundell TL (2012) Structural biology and drug discovery for protein-protein interactions. Trends Pharmacol Sci 33: 241-248.

62. Obrecht D, Chevalier E, Moehle K, Robinson J (2012) beta-Hairpin protein epitope mimetic technology in drug discovery. Drug Discov Today Technol 9: e1-e70.

63. Robinson JA (2008) Beta-hairpin peptidomimetics: design, structures and biological activities. Acc Chem Res 41: 1278-1288.

64. Guo Q, Robinson N, Mattson MP (1998) Secreted beta-amyloid precursor protein counteracts the proapoptotic action of mutant presenilin-1 by activation of NF-kappaB andstabilization of calcium homeostasis. J Biol Chem 273 12341-12351.

65. Cho PY, Joshi G, Johnson JA, Murphy RM (2014) Transthyretin-derived peptides as beta-amyloid inhibitors. ACS Chem Neurosci 5: 542-551.

66. Fasan R, Dias RL, Moehle K, Zerbe O, Obrecht D, et al. (2006) Structureactivity studies in a family of beta-hairpin protein epitope mimetic inhibitors of the p53-HDM2 protein-protein interaction. Chembiochem 7: 515-526. 